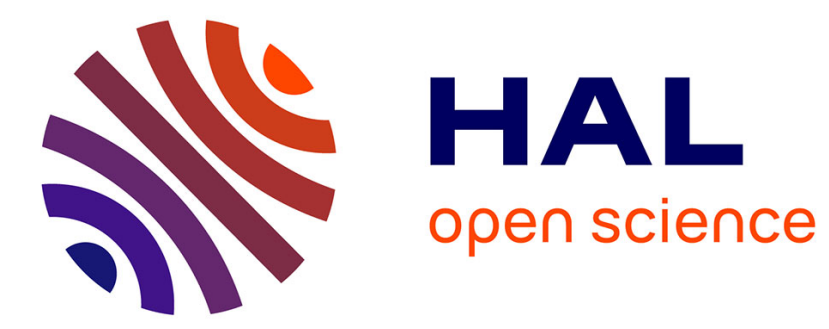

\title{
Phenotypic plasticity
}

\author{
Antonine Nicoglou
}

\section{To cite this version:}

Antonine Nicoglou. Phenotypic plasticity: From microevolution to macroevolution. Handbook of evolutionary thinking in the sciences, 2014, 978-94-017-9014-7. 10.1007/978-94-017-9014-7_14 . halshs01498604

\section{HAL Id: halshs-01498604 https://shs.hal.science/halshs-01498604}

Submitted on 30 Mar 2017

HAL is a multi-disciplinary open access archive for the deposit and dissemination of scientific research documents, whether they are published or not. The documents may come from teaching and research institutions in France or abroad, or from public or private research centers.
L'archive ouverte pluridisciplinaire HAL, est destinée au dépôt et à la diffusion de documents scientifiques de niveau recherche, publiés ou non, émanant des établissements d'enseignement et de recherche français ou étrangers, des laboratoires publics ou privés. 
Phenotypic plasticity: from microevolution to macroevolution Chapter 14

Antonine Nicoglou

LaBex “Who am I?", Université Paris Cité \& Institut d'Histoire et de Philosophie des sciences et des Techniques, Paris, France

antoninenico@gmail.com

Abstract: This chapter starts with a short history of the concept of phenotypic plasticity (from the seventeenth century to present) in order to distinguish two distinct conceptions of plasticity: one more dynamic (or Aristotelian) according to which the notion has been described as a property inherent to life whose very organization depends upon it, and an other conception, more passive, according to which "plasticity" means the capacity to express different phenotypes for a single genotype depending on environmental conditions. The chapter shows then how Darwinian theories have first favored the second conception, before the emergence of a renewed interest for the first one, which plays the role of an explanans, while the second conception would rather be an explanandum. In so doing, the chapter describes in depth the role of the concept in micro- and macroevolution study.

The concept of plasticity is everywhere in the life sciences. As in philosophy, ${ }^{1}$ the term can have two meanings: in the active sense, the concept of plasticity is synonymous with "that which has the power to shape or form" with the example in biology being the egg cell development, which has the plastic capacity to generate a multi-celled organism; in the passive sense, the concept expresses a "susceptibility to take on an indefinite number of forms", with the example in evolutionary biology being "phenotypic plasticity", which we will define here as an organisms' capacity to express different phenotypes of a single genotype as a function of environmental conditions. The concept of plasticity is then, in its passive sense, linked to evolu-

1 Godin (2004), Dictionnaire de philosophie, Fayard/éditions du Temps. 
tionary biology and its history. As Massimo Pigliucci ${ }^{2}$ points out, the issue of adaptation to changing environmental conditions is central to the study of a whole range of evolutionary issues; as a result, so is plasticity. The first part of this chapter retraces the history of the concept of phenotypic plasticity and its meanings in evolutionary biology. The second part explores the possible links between the concept and microevolution (the "observable" ${ }^{3}$ evolution of life). The third part analyses the possible consequences of these relationships as they pertain to controversies in macroevolution. In conclusion, I return to the idea Pigliucci proposes that the concept of plasticity will only prove useful when it comes to shedding light on ancient evolutionary issues that have until now remained unresolved.

\section{History of the concept of plasticity in evolution}

\subsection{The concept before it was formalized}

In the seventeenth century, the philosophers Henry More and Ralph Cudworth ${ }^{4}$ refer to the concept of "plastic nature" when they discuss the process of ontogenesis. This "plastic nature" evokes, in a blind and unconscious world, the Aristotelian "architectural" force that produces biological organization. It is this force that in some way provides the link between the body and the soul. The speculations of these metaphysicists', who promoted a form characteristic of panpsychism, ${ }^{5}$ raised the difficult issue of the legitimacy of a modeling of life that was developing at the margins of a mechanistic understanding. ${ }^{6}$ The laws of physics that explained the world's mechanical phenomena could not uniquely explain life, with this capacity to "develop",

2 Pigliucci (2001), Phenotypic Plasticity: Beyond Nature and Nurture, Johns Hopkins University Press, p. 238.

3 Evolution that is generally considered as being observable is the evolution in a given species within a relatively restrained period and with a rate of mutations that is not too large.

4 More (2011), The immortality of the soul, so far as it is demonstrable from the knowledge of nature and the light of reason [1659], Eebo Editions. Cudworth (1964), The True Intellectual System of the Universe Wherein all the Reason and Philosophy of Atheism is Confuted: and its Impossibility Demonstrated [1678], Frommann.

5 For a detailed presentation of these questions, cf. Duchesneau (1998), Les modèles $d u$ vivant de Descartes à Leibniz, Vrin.

6 Descartes (1641), Méditations métaphysiques. 
producing newness from the remainders of preceding generations. These philosophical reflections led to the notion of a plastic property inherent in life, and whose very organization depended upon it.

While developing his theory of evolution by the path of natural selection two centuries later (1859), Darwin pointed out a new aspect of the concept of plasticity, associating it with "external conditions". ${ }^{7}$ In chapter V of On the Origin of Species dealing with the laws of variation, he observed that certain organisms belonging to the same species could adopt variable characters as a function of their conditions of existence. Based on these observations he did not, however, establish a law of nature. Darwin, unlike Lamarck, ${ }^{8}$ did not consider the direct action of ambient conditions as a factor that determined variation. For him, the origin of variation was random, and its foundation lies in the "nature of the organism" more than in external conditions. Darwin nevertheless observes that "The direct action of changed conditions leads to definite or indefinite results [depending on the nature of the organism]. In the latter case the organization seems to become plastic [...]". ${ }^{9}$ In this view, Darwin associates the organism's plasticity with the "indeterminate" (changing) effects external conditions' action on the organism.

In On the Variation of Plants and Animals, he presents an entirely different vision of plasticity, closer this time to the idea of a property that would be inherent in the organization of all living beings. Confronted with the question of knowing whether the cause and the form are guided by a specific design, Darwin suggests that if all variations were predetermined, then "that plasticity of organization, which leads to many injurious deviations of structure, as well as the redundant power of reproduction which inevitably leads to a struggle for existence, and, as a consequence, to the natural selection or survival of the fittest, must appear to us superflu-

7 What Darwin calls "external conditions" corresponds to what is today called "environment" or "environmental factors", which are distinct from "genetic factors" and that Darwin distinguished at the time as "the nature or the constitution of the organism".

8 For Lamarck, external conditions have a determining role in the establishment of variation, as he shows in the first part of Philosophie zoologique (1809).

9 Darwin (1876), The Origin of Species by Means of Natural Selection [...], John Murray, 6th ed., chap. V: "Laws of Variation". 
ous laws of nature". ${ }^{10}$ In the hierarchy Darwin lays out, the plasticity of organization seems to be a prerequisite for evolution and one of the fundamental characteristics of life; he goes so far as to call it a "law of nature". Later on, research on plasticity tended to focus not on Darwin's conception of it, but essentially on the first notionthe issue of variation and its relationship to external conditions.

\subsection{The Soviet School and the Norm of Reaction: Plasticity, a Property of the Genotype}

After the discovery of Mendel's laws and proof of the discreet nature of Mendelian factors, the saltationist theory ${ }^{11}$ as a main mechanism to explain changes in the course of evolution came into vogue. Faced with this new trend, the zoologist Richard Woltereck (1877-1944) was a defender of the Darwinian conception. His studies ${ }^{12}$ on different varieties of Daphnia (water fleas) on continuous traits such as head size as a function of different nutrient levels allowed him to show phenotypic variations among lines in a given nutritive environment. He then drew "phenotype curves" to describe this phenomenon. ${ }^{13}$ Given that the curves can differ for each new variable, an infinite quantity of curves can thus be represented. Woltereck called the sum of relationships among these curves Reaktionsnorm (norm of reaction). According to him, it is this norm of reaction that is transferred and thus inherited. ${ }^{14}$ In this way, Darwinism is

10 Darwin (1875), The Variation of Animals and Plants Under Domestication, John Murray, $2^{\text {nd }}$ ed., vol. 2.

11 The saltationist theory stands in opposition to the Darwinian concept of evolution since it considers that evolution can only take place via quantitative "leaps" and not in a continuous and gradual fashion as Darwin had shown (cf. Heams "Variation", Chap. 2, this volume).

12 Woltereck (1909), "Weitere experimentelle Untersuchungen über Artveränderung, speziel über dasWesen quantitativer Artunterschiede bei Daphnien", Verhandlungen der Deutschen Zoologischen Gesellschaft, 19.

13 The historical study presented by Sarkar (1999, "From the Reaktionsnorm to the adaptive norm: The reaction Norm, 1909-1960", Biology and Philosophy, 14) on the norm of reaction reproduces a number of outlines and curves Woltereck made in 1909.

14 Wilhelm Johannsen (1857-1927), known for having introduced in 1909 the distinction between genotype and phenotype, believed that Woltereck's curves explained the possible phenotypes for a given genotype. For Woltereck, interpreted the genotype as an agent that allowed for phenogenesis using the reaction norm (cf. note 16), Johannsen saw it as a determining agent. It is this concept of the reaction norm that would endure. (For a study of this debate, cf. Sarkar, 1999, op. cit.) 
"saved" from saltationism since, according to Woltereck, with the norm of reaction selection will act upon small gradual changes.

The concept of the norm of reaction, taken up again by Johannsen, was initially the standard-bearer of the complexity of nature-nurture interactions ${ }^{15}$ before becoming a tool for general analysis of phenogenesis ${ }^{\mathbf{1 6}}$ in the 1920s. In the Soviet Union, the geneticists D.D Romaschoff and Nikolay Timoféeff-Ressovsky ${ }^{17}$ started a research program to attempt to identify different factors' (genetic and external) roles on phenogenesis. Their results did not conclude that there was a clear tendency in favor of the dominance of genetic factors or of environmental factors in establishing phenotype ${ }^{18}$ However, Oscar Vogt gave a genocentric interpretation in 1926, which introduced the concept of "expressivity" to describe the extent (in probabilistic terms) of the manifestation of a genetic mutation for a given individual, as well as the concept of "penetrance", describing the proportion of individuals with a genetic mutation but who do not show any effect from this mutation. ${ }^{19}$ Conrad Waddington ${ }^{20}$ would later take up these terms and introduce them to England. Beginning in 1950, penetrance comes to be defined as the conditional probability that a phenotype appears for a given gene. Variability in the trait's phenotypic manifestation becomes the result of the "gene's expression" and of its indirect "penetrance". It is not longer a matter of the environment and the distinction between the two notions begins to disappear.

15 See Hogben (1939), Nature and nurture, G. Allen \& Unwin Ltd. The nature-nurture debate tends to oppose partisans of the concept that complex human traits like intelligence depend more on genes and those who consider them to depend more on culture, childrearing, or more generally the environment. For our purposes here, nurture refers to the sum of all "environmental" factors.

16 This term is used to qualify the development or ontogenesis of a phenotype and emphasizes the process rather than the single causal link associating the genotype with the phenotype.

17 Romaschoff (1925), "Über die Variabilität in der Manifestierung eines erblichen Merkmales (Abdomen abnormalis) bei Drosophila funebris F", Journal für Psychologie und Neurologie, 31. Timoféeff-Ressovsky H.A. \& Timoféeff-Ressovsky N.W. (1926), “Über das phänotypische Manifestation des Genotypes. II. Über idio-somatische Variationsgruppen bei Drosophila funebris, Wilhelm Roux", Archiv für Entwicklungsmechanik der Organismen, 108.

18 For a report on these controversies, See Sarkar (1999, op. cit.).

19 Vogt (1926), "Psychiatrisch wichtige Tatsachen der zoologisch-botanischen Systematik", Journal für Psychologie und Neurologie, 101.

20 Waddington (1938), An introduction to modern genetics, G. Allen \& Unwin Ltd. 
With this interpretation, the reaction norm tends to become a theoretical tool for genetics where it had earlier only been a way to model phenotype-environment interactions.

\subsection{Schmalhausen and Dobzhansky: The adaptive norm of reaction}

The distinction between the adaptive and non-adaptive norm of reaction is based on organic selection, ${ }^{21}$ which consists of the assimilation of a modified phenotype by the integration of a genetic mutation in the organism's genome, a mutation whose effect leads to the same modified phenotype. This theory, which became much more well known as "the Baldwin Effect", ${ }^{22}$ initially popularized by Ivan I. Schmalhausen, who also replaced the term "organic selection" with "stabilizing selection" thereby emphasizing the stabilization of the adaptive phenotypic response by its "transformation" into a genotypic response leading to the same phenotypic effects while assuring the transmission of this response to future generations. Schmalhausen also relied on experiments with mutagenesis carried out in 1926 by Theodosius Dobzhansky, on the fruit

21 Baldwin was the first to formulate "Organic selection" (1896, "A New Factor in Evolution", American Naturalist, 30) after he completed studies on learning in children. He showed that because of their ability to learn, individuals survived by adapting to adverse environmental conditions. If the environment did not vary sharply, the most adaptive mutations would be those that transform what had to be learned into something congenital. Learning "guides" evolution, since it introduces a bias for durable mutations. The ability to learn augments the population's genetic variance. When there is a dramatic change in the environment, only very different individuals (that exist due to their capacity to learn) can survive. Learning "accelerates" evolution and allows for evolutionary leaps. (This notion was later outlined in detail by Osborn, 1897, "The Limits of Organic Selection", American Naturalist, 31; Lloyd Morgan, 1900, Animal behavior, E. Arnold; and first experimented by Gause, 1947, "Problems of Evolution", Transaction of the Connecticut Academy of Sciences, 37.)

22 Baldwin (1896, op. cit.). Baldwin's idea, which was distinct from Larmarckism of the day, was that behavior could affect the action of natural selection, even facilitating it. Today the Baldwin Effect is interpreted as follows: phenotypic plasticity can facilitate evolution by natural selection, according to the particular combination of forms of reaction norms and selection pressures in a given population of organisms (in particular, if certain reaction norms produce a viable phenotype in a new environment, then the genotypes associated with it will have a chance of surviving, and the population will have a chance to continue on). Cf. Pigliucci (2010), "Phenotypic plasticity", in Pigliucci \& Müller (eds.), Evolution, the extended synthesis, MIT Press. For a detailed analysis of contemporary debates on the Baldwin effect, cf. Weber \& Depew (2003), Evolution and learning: the Baldwin effect reconsidered, MIT Press. 
fly. Dobzhansky showed that a mutant phenotype characterized in this case by an abnormality in the development of the abdomen, did not appear for generations if the food the animal consumed was dry. However, the mutation appeared immediately if the offspring were fed a moist diet. Based on these observations, he concluded that if environmental factors could induce a character, then it was the unchanged norm of reaction that was inherited. Schmalhausen took up this idea as well, but made the distinction between what he called the "adaptive norm" and the "morphosis". The adaptive norm refers to situations where the expression of adaptive modifications transforms the entire organization. Conversely, morphoses are of a different nature, they survive as new punctual reactions that have not yet acquired an historical basis (linked for example to new environmental factors or to a reaction norm that has been disturbed following a genetic mutation. ${ }^{23}$ This adaptive norm is a fundamental idea, since it implies that any modification is only possible as a function of strict limits determined by the norm. Modification itself must not be considered an adaptation; rather, it is the "confinement" of this modification within very precise limits.

Waddington developed “canalization", a similar notion, later on in England. ${ }^{24}$ He distinguished "genetic canalization", ${ }^{25}$ which referred to a genotype's ability to produce two distinct phenotypes, from "environmental canalization", which referred to a genotype's capacity to produce a single phenotype in varied environments.

Canalization is generally defined as the developmental processes' intrinsic robustness in response to genetic or environmental disruptions. Waddington also defined the corollary notion of "genetic assimilation" ${ }^{\text {26 }}$ linked to the Baldwin effect. Genetic assimilation implies that the new canalized trait will ultimately be (genetically) stabilized, and that this will happen whether or not the environmental circumstances leading to the disruption continue.

23 Schmalhausen (1986), Factors of evolution: the theory of stabilizing selection [1949], University of Chicago Press.

24 Waddington (1942), "Canalization of Development and the Inheritance of Acquired Characters", Nature, 150.

25 As shown in the sections that follow, this phenomenon is now better known as "pleiotropy".

26 Waddington (1953), “Genetic assimilation of an acquired character", Evolution, 7(2). 
Dobzhansky, by spreading the notion of the adaptive norm to the West, ${ }^{27}$ especially the United States, showed that a mutation does not modify a particular morphological character, but rather introduces a change in the norm of reaction. Over time, the notion of "norm of reaction" was replaced by "reaction range", indicating that phenotypic variability depends largely on interactions between heredity factors and the environment. Emphasis is thus placed on environmental plasticity. Dobzhansky's $^{28}$ use of the term "norm of reaction" led to its conceptual modification, ${ }^{29}$ which, beginning in 1955, essentially turned, into a concern of population genetics. Plasticity was considered to be just another trait subject to natural selection.

\subsection{Bradshaw and the genetic control of phenotypic plasticity}

In 1965, Anthony D. Bradshaw was the first to propose a model to explain the evolution of the norm of reaction based on the genetic control of plasticity. According to Bradshaw, plasticity is demonstrated by the potential alteration of the genotype's expression under the effect of environmental influences. He referred to the notion of “phenotypic plasticity", which had first been used in 1914 by Herman Nilsson-Ehle ${ }^{30}$ to describe an individual's ability to adapt to extreme environments by developing alternative phenotypes (alpine plant adaptations to lower altitudes). For example, the migratory locust Schistocerca gregaria can adopt two different phenotypes in relation to environmental conditions (it will be green with small wings if dietary sources are limited, or dark with large wings if food is more abundant). The notion of "phenotypic

27 This term is used here to highlight the ideological and theoretical gap at the time separating the Soviet Union from Western Europe and the United States, especially with regard to explanations based on genetics and biology. Nevertheless, these differences did lead to important work, such as Dobzhansky's, among others, whose research illustrated just how much could be gained from attempts to reconcile these two conceptual poles. Dobzhansky would become one of the creators of the synthetic theory of evolution. Dobzhansky (1955), Evolution, genetics, and man, John Wiley and Sons.

29 This modification seems to result from a divergence of the two scientists' interests. Schmalhausen was mainly concerned with issues based on the study of phenogenesis, which fascinated a large number of Soviet biologists at the time. For his part, Dobzhansky, wanted to achieve a sort of compromise between the Soviet view of the norm of reaction and the genocentrism Johannsen advocated.

30 Nilsson-Ehle (1914), "Vilka erfarenheter hava hittills vunnits rörande möjligheten av växters acklimatisering”, Kunglig Landtbruks-Akaemiens. Handlinger och Tidskrift, 53. 
plasticity" became more common in the literature after Bradshaw's publication of his article on it in $1965 .^{31}$ In his research, he concentrated on "adaptive plasticity" and considered it to be controlled by specific genetics. Bradshaw based this claim on the observation that plasticity was not a property of the entire genome, but rather a property unique to individual characters in relation to specific environmental influences. In addition, since a trait's plasticity varies among different species within the same genus and among different varieties of the same species, Bradshaw concluded that genetic control over character was independent from that of the character's plasticity. He ultimately referred to Waddington's research on canalization and genetic assimilation, pointing out that if stability is under the control of genetics, it must be the same with plasticity, which, by definition, stands in opposition to stability. These different arguments allowed Bradshaw to assume that plasticity, controlled by genetics, was also necessarily subject to natural selection like any other trait.

\subsection{Evolution of phenotypic plasticity}

\subsubsection{Testing adaptive plasticity ${ }^{32}$}

To prove Bradshaw's hypothesis, it was necessary to identify what action natural selection exerted on plasticity and thus to analyze its evolution. In 1985, Russell Lande and Sara Via established the first models of quantitative genetics ${ }^{33}$ that could

31 Bradshaw, "Evolutionary significance of phenotypic plasticity in plants", Advances in Genetics, 13.

32 Via \& Lande (1985), "Genotype-environment interaction and the evolution of phenotypic plasticity", Evolution, 39. Schlichting (1986), "The evolution of phenotypic plasticity in plants", Annual Review of Ecology, Evolution and Systematics, 17.

33 Quantitative genetics studies the genetic components that explain variation of quantitative characters (size, coat color, growth rate, concentration of a molecule, etc.) and their inheritability. It has become a classic tool in biology (Fisher, 1930, The genetical theory of natural selection, Clarendon Press; Wright, 1951, "The genetical structure of population", Annual Eugenics, 15; Falconer, 1981, Introduction to quantitative genetics, Longman; Roff, 1997, Evolutionary quantitative genetics, Chapman \& Hall) and has been the subject of an ongoing revival in many fields of evolutionary biology (Lande, 1980, "Genetic Variation and Phenotypic Evolution During Allopatric Speciation", The American Naturalist, 116 (4); Cheverud et al., 1983, "Quantitative genetics of development: genetic correlations among age-specific trait values and the evolution of ontogeny", Evolution, 37(5); Lande \& Arnold, 1983, "The measurement of selection on correlated characters", Evolution, 37(6) ; Slatkin, 1987, "Quantitative genetics of heterochrony", Evolution, 41(4); Barton \& Turelli, 1989, “Evolutionary Quantitative Genetics : How Little Do We Know ?”, 
be used to evaluate the evolution of "phenotypic plasticity" (the notion that was henceforth used to describe phenotypic response to environment). This work opened up a new avenue for research. The main goal was to clarify natural selection's distinct action on plasticity. These models did, however, raise new questions. It is possible to measure the evolution of plasticity for a species in environments that vary (i.e. the Pontia butterfly whose wing pigmentation is more or less vivid depending on the season in which it develops), but it is also possible to try to measure intergenerational plasticity when successive generations are subject to fluctuating environments (example: the effects of climate change on certain plants and their progressive transformation). In order to differentiate these two situations, the notion of "labile" or "nonlabile" traits is borrowed from Schmalhausen. "Labile traits" refer to the fact that an individual adjusts its phenotypic expression throughout its life (i.e. a plant will react to the amount of water in its environment its entire life), whereas the "non-labile" traits indicate that the expression of traits is fixed once and for all during development. In the first case, the norm of reaction evolves toward an optimum (the plant will get used to the average amount of water available to optimize its growth). In the second case, the situation is much more complex and the equilibrium that is reached depends on the intensity and duration of the environmental fluctuations to which the populations are subjected. Based on these studies, Via drew two major conclusions: (1) Natural selection acts on character states expressed within particular environments. (2) Selection acts within each environment to adjust the mean phenotype expressed there toward its optimum value. ${ }^{34}$ It follows from this that the evolution of adaptive reaction norms can only occur by way of phenotypic traits themselves. Selection would not thus act directly upon plasticity, which Via did not consider to be a distinct trait with its own genetic etiology. The question remains one of knowing

Annual Review of Genetics, 23(1); Shaw et al., 1995, "Changes in Genetic Variances and Covariances : G Whiz !", Evolution, 49(6). It thus makes sense that these techniques have been used to study phenotypic plasticity as well (Falconer, 1952, "The Problem of Environment and Selection", The American Naturalist, 86(830); Via, 1984, "The Quantitative Genetics of Polyphagy in an Insect Herbivore. II. Genetic Correlations in Larval Performance Within and Among Host Plants", Evolution, 38(4)).

34 Via et al. (1995), "Adaptative phenotypic plasticity: Consensus and controversy", Trends in Ecology and Evolution, 10(5). 
what the correlation is between the evolution of plasticity and the evolution of the expressed trait in the environment.

Conversely, the biologist Carl Schlichting appeared to demonstrate in a 1986 article comparing two species of purslane (Portulaca grandiflora and Portulaca oleraca) that a trait's plasticity could evolve independently from this trait. He used the example of the qualitative character "shoot/root ratio". He observed that even if the average of this trait for varying environments was identical for the two species, the degree and direction of the plastic response could differ. Schlichting concluded that genetic control of plasticity could only be distinct from the trait. The study of plasticity's evolution seems to essentially rest on the knowledge of its genetic control. Biologists like Peter van Tienderen and Gerdien de Jong ${ }^{35}$ established quantitative models to show plasticity's variation. Again, these models seemed to confirm the existence of "plasticity genes" 36 " by way of their demonstration of an independence between the evolution of the trait's average and the evolution of plasticity. Nevertheless, because of the controversy Via introduced, even if a genetic control for plasticity seemed to exist, the issue of defining this "genetic control" still remained.

\subsubsection{Defining “plasticity genes" 37}

In 1991, Scheiner and Lyman established a classification for what they considered the "genetic bases of plasticity". ${ }^{38}$ They asserted that three distinct categories corre-

35 Van Tienderen \& Koelewijn (1994), "Selection on Reaction Norms, Genetic Correlations and Constraints", Genetics Research, 64(2). De Jong (1995), "Phenotypic Plasticity as a Product of Selection in a Variable Environment", The American Naturalist, 145(4).

36 The expression "plasticity genes" in the plural indicates that it has become clear that the causal linear model between a single gene and a phenotype is rarely the right one. Models that are developed are thus "polynomial" models that account for these genes' plurality.

37 Scheiner \& Lyman (1991), "The genetics of phenotypic plasticity. II. Response to selection", Journal of Evolutionary Biology, 4(1). Schlichting \& Pigliucci (1993), "Control of Phenotypic Plasticity Via Regulatory Genes", The American Naturalist, 142(2).

38 Sheiner and Lyman's concept is less clear-cut than de Jong and van Tienderen's, since it does not identify "plasticity genes" properly speaking, but rather bases of their genetic expression. 
sponded to the genetic bases of the plastic response. First is "overdominance"39 expressing the fact that there is an inversely proportional relationship between heterozygosity $^{\mathbf{4 0}}$ and plasticity: the homozygotic a genotype is, the more its reaction norm (its phenotypic response according to the environment) will be plastic. This model, without fundamentally demonstrating it, considers plasticity to be in some ways an "accident" that results from a loss or reduction of homeostasis ${ }^{41}$ in a genotype leading to excess homozygosity of the genotype..$^{42}$ Secondly, "pleiotropy" indicates that plasticity is a function of the differential expression of the same gene (of the same group of alleles) in different environments, ${ }^{43}$ analogous to the classical quantitative genetic case where several traits share a common genetic control of genes' pleiotropic effects. Finally, "epistasy" indicates that two classes of genes control the two fundamental characteristics of a reaction norm: its plasticity and its general average. Plasticity is caused by the interaction between genes that determine the magnitude of the response to environmental effects with genes that determine the character's average expression. ${ }^{44}$ This model assumes, contrary to Via's, that the trait mean and the environmental variance are two independent characteristics. ${ }^{45}$ For the two authors, ${ }^{46}$

39 The concept of overdominance begins with Lerner's original work (1954), Genetic homeostasis, John Wiley, et de Waddington (1961), "Genetic Assimilation” in Caspari \& Thoday (eds.), Advances in Genetics, Academic Press.

40 Heterozygosity: genotypic situation in which to homologous loci of a single pair of chromosomes each carries a different allele. Homozygosity: presence of the same allele on both chromosomes in pair.

41 Genetic homeostasis or "return to equilibrium" involves a homogeneous distribution between maternal and paternal alleles leading to heterozygosity. For a discussion of the relationships between plasticity and heterozygosity, cf. Pigliucci (2001), Phenotypic Plasticity: Beyond Nature and Nurture, Johns Hopkins University Press.

42 Lerner (1954), Genetic homeostasis, John Wiley. Gillespie \& Turelli (1989), “GenotypeEnvironment Interactions and the Maintenance of Polygenic Variation", Genetics, 121(1).

43 Falconer (1981), Introduction to quantitative genetics, Longman. Via \& Lande (1985), "Genotype-environment interaction and the evolution of phenotypic plasticity", Evolution, 39. Idem (1987), "Evolution of Genetic Variability in a Spatially Heterogeneous Environment: Effects of Genotype-environment Interaction”, Genetics Research, 49(2). Via (1987), "Genetic constraints on the evolution of phenotypic plasticity", in Loeschcke (ed.), Genetic constraints on adaptive evolution, Springer-Verlag.

44 Lynch \& Gabriel (1987), "Environmental Tolerance", The American Naturalist, 129(2). Jinks \& Pooni (1988), The genetic basis of environmental sensitivity, Sinauer Associates. Scheiner \& Lyman (1989), "The genetics of phenotypic plasticity I. Heritability", Journal of Evolutionary Biology, 2(2).

45. Lynch \& Gabriel (1987), "Environmental Tolerance", op. cit. 
these three models are not mutually exclusive, and, moreover, the use of these categories applies to effects that appear not in one single environment, but rather in environments that differ over time.

This approach is essentially phenomenological, based on the observation of "types" rather than on the investigation of real causes of plasticity. Statistical studies in quantitative genetics are often used to study models without it being necessary to know the genes' actual role. ${ }^{47}$

Via's position, first rejected by the polynomial approach, ${ }^{48}$ has still not been totally rejected. ${ }^{49}$ More specifically, for Via, the "so-called" independence between the "trait mean" and plasticity remains to be confirmed. She shows that the "trait mean" can also be measured for a single environment (variability independent of environment) just as it can from a possible range of expressions of the trait that in this case reflect the variation of environments in which the trait would be expressed. In this last instance, Via calls the trait mean the grand mean. She suggests that the distinction between these two situations (trait mean and grand mean) once again leads to the problem of the correlation between the trait's evolution and the evolution of plasticity. For the case of the trait of "shoot/root ratio", the trait's general mean can be the same in two different species (comparatively, the two species will both grow as much) while the trait mean will be different for each of the species in a single environment (one of the species will grow more than the other in environment $\mathrm{E}_{1}$ and inversely in environment $\mathrm{E}_{2}$ ). This means that different species of plants will grow differently in the same environment, but overall, if these different species are

46 Scheiner \& Lyman (1991), "The genetics of phenotypic plasticity. II. Response to selection", Journal of Evolutionary Biology, 4(1).

47 de Jong (1995), "Phenotypic Plasticity as a Product of Selection in a Variable Environment", The American Naturalist, 145(4).

48 Van Tienderen (1991), "Evolution of Generalists and Specialist in Spatially Heterogeneous Environments", Evolution, 45(6). Scheiner (1993), "Genetics and Evolution of Phenotypic Plasticity", Annual Review of Ecology and Systematics, 24(1). Van Tienderen \& Koelewijn (1994), "Selection on Reaction Norms, Genetic Correlations and Constraints", Genetics Research, 64(2).

49 For a discussion of different perspectives and approaches to adaptatie phenotypic plasticity, cf. Via et al. (1995), "Adaptative phenotypic plasticity: Consensus and controversy", Trends in Ecology and Evolution, 10(5). 
subjected to changing environments, their average growth will be identical. Via again maintains the idea that phenotypic plasticity is not a specific trait, but rather an epiphenomenon resulting from the selection of different averages of the phenotypic character in different environments.$^{50}$ For Via, the model will thus be more complex than it first seems, since there will need to be an interaction, however indirect, between the two variables.

To resolve this controversy, which they dub a semantic wrangling more than a true problem between Via's position and the polynomial approach, Schlichting and Pigliucci offer the definition of "plasticity genes" as "regulatory loci that exert environmentally dependent control over structural gene expression and thus produce a plastic response" ${ }^{51}$ For these two researchers, these two possibilities (the existence of plasticity genes versus plasticity as a by-product of selection) are not mutually exclusive; proof of the existence of plasticity genes in the literature of the past ten years seems to confirm their hypothesis as with the paradigmatic example of genes coding for plant,$^{52}$ phytochromes. ${ }^{53}$

\subsubsection{Molecular control of plasticity ${ }^{54}$}

50. Via (1993), “Adaptive Phenotypic Plasticity: Target or By-Product of Selection in a Variable Environment?", The American Naturalist, 142(2).

51. Schlichting \& Pigliucci (1993), "Control of Phenotypic Plasticity Via Regulatory Genes", The American Naturalist, 142(2).

52. Ballaré (1999), "Keeping up with the neighbours: phytochrome sensing and other signalling mechanisms", Trends in plant science, 4(3). Genes coding for light sensitivity in plant phytochromes comprise one of the major examples of plasticity genes. For an explicit test of the adaptive hypothesis of plasticity by a measure of relative fitness of alternative phenotypes in a range of environments and on the particular example of the character "phytochrome-mediated stem elongation" in response to the shade avoidance, using transgenic and mutant plants in which this plastic response has been deactivated, cf. Schmitt et al. (1995), "A test of the adaptive plasticity hypothesis using transgenic and mutant plants disabled in phytochrome-mediated elongation responses to neighbors", American Naturalist, 146(6).

53. Phytochromes are pigmented photoreceptors in plants. They play an important chronobiological role (in germination, blossoming, etc.). ( $N d d$.)

54 . Smith (1990), "Signal perception, differential expression within multigene families and the molecular basis of phenotypic plasticity", Plant, Cell \& Environment, 13(7). Schmitt et al. (1995), op. cit. Van Tienderen et al. (1996), "Pleiotropic Effects of Flowering Time Genes in the Annual Crucifer Arabidopsis thaliana (Brassicaceae)", American Journal of Botany, 83(2). Callahan et al. (1997), "Developmental phenotypic plasticity: where ecol- 
In 1996, Pigliucci returned to the 1995 definition of "plasticity genes", limiting it to the notion of "regulatory loci that directly respond to a specific environmental stimulus by triggering a specific series of morphogenic changes". This definition does not, however, mean that all regulator genes are plasticity genes, for the simple reason that all regulator genes do not react to environmental stimuli. ${ }^{55}$ The genetic basis of any plastic response will necessarily include, in a significant way, more genes than those that are directly linked to detection of the environment. Yet the demonstration of this category (genes directly linked to the detection of the environment) is conceptually important, since its existence cannot be explained without referring to the action of natural selection. This is why it has gained the specific attention of biologists interested in the molecular bases for plasticity.

In 1990, Harry Smith explored this molecular path in a special issue of Plants, Cells and Environment dedicated to "sensing the environment". He wanted to know about the type of molecular mechanisms that linked the perception of environmental signals with specific developmental responses (corresponding to phenotypic plasticity). Beginning with this study, he concluded that it is the differential regulation of the expression of multigene family members that represented the molecular basis of phenotypic plasticity. ${ }^{56}$

The first molecular studies on genotype-environment reactions showed the existence of specific responses brought on by a particular type of stress, responses caused by a limited number of constraints and generalized responses to a variety of stressful situations. As a result, epistasy and pleiotropy at the molecular level gained renewed interest, which progressively made the interpretation of plastic reaction diagrams quite difficult in the absence of any molecular information. ${ }^{57}$

ogy and evolution meet molecular biology", BioEssays, 19(6).

55 Pigliucci (2001), Phenotypic Plasticity: Beyond Nature and Nurture, Johns Hopkins University Press.

56 Smith (1990), "Signal perception...", op. cit.

57 At this time the concepts of epistasis and pleiotropy were developing at the molecular level, which were not the same as those that had been used in the sense of quantitative genetics. On the genes' pleiotropic effects and their evaluation for different phenotypic levels, cf. van Tienderen et al. (1996), "Pleiotropic Effects of Flowering Time Genes in the Annual Crucifer Arabidopsis thaliana (Brassicaceae)", American Journal of Botany,83(2). 
One general observation became clear after these different studies of the molecular level: in the course of the past twenty years, the expression "plasticity genes" has slowly disappeared. This is not because the proof of a genetic control of plasticity has not been serious enough (much to the contrary, different studies seem to confirm it), but because the question of a direct or indirect link between genes and characters has increasingly been abandoned in favor of questions dealing with proximal causes of plasticity. Today the question would be better phrased as: is plasticity characterized by a simple allelic sensitivity, or is it controlled by genes that carry out a regulatory role on the genes control it upon which the trait depends?

Reframing the issue as a result of extending of the field of investigation into molecular biology develops the idea Schmalhausen and Waddington initially proposed that the reaction norm is transferable and can evolve. It is effectively accepted that there is no direct causal link between a genotype and a phenotype, ${ }^{58}$ and that the phenotype is the product of a complex epigenetic system that integrates both genes capable of interacting with internal and external signals as well as genes capable of producing these very signals. It is these complex epigenetic systems that are inherited by evolution, and not specific allelic or genetic variations. ${ }^{\mathbf{5 9}}$ From this perspective, an important amount of molecular and physiological work has focused directly on the molecular basis of phenotypic plasticity. ${ }^{60}$

These researches, which initially focused on genetic bases of plasticity, have not however been limited to single genes. Thus, the functionally flexible hormonal systems of plants and animals provide a starting point for understanding how envi-

58 For a discussion of the question of knowing whether a gene can be considered as being genes "for” trait, cf. Kaplan \& Pigliucci (2001), "Genes 'for' phenotypes: a modern history view", Biology and Philosophy, 16(2).

59. The first to raise this question of epigenetic heredity was Maynard Smith (1990), "Models of a dual inheritance system", Journal of Theoretical Biology, 143(1).

${ }^{60}$. For example, Smith (1990), "Signal perception, differential expression within multigene families and the molecular basis of phenotypic plasticity", Plant, Cell \& Environment, 13(7); Callahan et al. (1997), "Developmental phenotypic plasticity: where ecology and evolution meet molecular biology”, BioEssays, 19(6); Aubin-Horth \& Renn (2009), “Genomic reaction norms : using integrative biology to understand molecular mechanisms of phenotypic plasticity", Molecular Ecology, 18(18). 
ronmental signals are translated, interpreted, and how organisms respond to them. ${ }^{61}$ Hormones effectively constitute the main interface between the genetic level of action and the external environment, in the sense that they play two important roles: they shape the organism and they transport the information from environmental receptors, which triggers specific reactions that characterize phenotypic plasticity. ${ }^{62}$

Even if over the course of these years, plasticity's genetic basis seemed to be confirmed, changes in the understanding of characters' determinism led biologists to a reinterpretation of plasticity's proximal causes. From this perspective, the biologist Mary Jane West-Eberhard, a specialist in insect behavior, provided a new approach in which phenotypic plasticity constitutes a cause of adaptation rather than a result.

\subsection{The theory of "developmental plasticity"63}

West-Eberhard was the first to link morphological plasticity with behavioral plasticity, and to take a position favoring a common role of these two phenomena to explain the evolution of phenotypic novelties ${ }^{64}$. Over the course of many years, she studied bees' social behaviors related to the diversity of their morphologies (size, presence

61 Friml \& Sauer (2008), "Plant biology: in their neighbour's shadow", Nature, 453(7193).

62 On these questions, Nijhout (2003, "Development and Evolution of Adaptive Polyphenisms", Evolution and Development, 5(1)) has concluded that the development of alternative phenotypes (in the reaction norms as well as for polyphenisms*) could be caused by specifically evolved mechanisms that are themselves regulated by variation of hormone secretion. Badyaev (2005, "Stress-induced variation in configuration: from behavioural plasticity to genetic assimilation", Proceedings of the Royal Society B, 272(1566)) thinks that phenotypic assimilation to the stress response is facilitated by the shared participation of nervous and endocrine pathways of the stress response for other functions in the organism. Lastly, Crespi \& Denver (2005, "Roles of stress hormones in food intake regulation in anuran amphibians throughout the life cycle", Comparative Biochemistry and Physiology-Part A: Molecular \& Integrative Physiology, 141(4)) have pointed out that the center neuro-endocrine stress represents a phylogenetically ancient signaling system that allows the fetus or larva to adapt its rhythm of development to prevailing environmental conditions.

[* $N d d$ : Group of morphological, behavioral, and psychological variations in a given species. Animals that undergo metamorphosis present very characteristic morphological polyphenisms.]

63 West-Eberhard (2003), Developmental plasticity and evolution, Oxford UP.

64 Phenotypic novelty is said to exist when there is the sudden appearance of a quantitatively different character that has not previously existed in an individual or a population of individuals. 
or absence of reproductive organs and of secondary sexual characters). In 2003, she proposed, in a work of synthesis entitled Developmental Plasticity and Evolution, ${ }^{65}$ an explanatory overview that accounted for the interaction of organisms with their environments. This explanation rested largely on the concept of "developmental plasticity". From her twenty years of studying insects' behavior as it related to their environment, West-Eberhard was convinced that a new synthesis of the theory of evolution that accounted for development was necessary. ${ }^{66}$ Though most of the theories that explain phenotypic diversity continued to be based primarily on studies of quantitative genetics, West-Eberhard decided to reverse the priorities by moving the evolution of the genome into the background in order to concentrate mainly on phenotype ${ }^{67}$ In her approach, gene selection operates indirectly: it is the phenotype that is selected first. This model creates a place for non-genetic factors in order to explain the origin of the phenotypic variation that is then selected ${ }^{68}$ Rather than trying to simplify the explanatory framework (limiting it to one single cause that would be the gene), West-Eberhard's approach consists of making it more complex by integrating different elements that could be generators of variations (environment,

65 For a critical discussion critique of West-Eberhard's work, Developmental Plasticity and Evolution, cf. Nicoglou (2011), «Expliquer la forme», Critique, 764-765.

66 This trend is called Evo-Devo for "Evolutionary Developmental synthesis" and arises out of a desire to restore development to the place it had lost during the years 1940-1960 as a result of the synthetic theory of evolution and the discoveries in genetics and population genetics to explain evolutionary processes. [ $N d d$ : on Evo-Devo, cf. Balavoine's chapter, this volume.]

67 By taking up again the classical definition of an organism's phenotype as the group of traits other than its genome (Johannsen, 1911, "The genotype conception of heredity", American Naturalist, 45), West-Eberhard offers a theoretical framework in which the genome is considered as a "physical" component in the same way as the environment (each one shaping the future organism); the phenotype is thus, in some way, the "consequence" of these physical factors' expression and its fulfillment depends in large part on the developmental component. For this reason, West-Eberhard suggests that it is more sound to explain traits' evolution by starting with phenotypic variations rather than on single genetic variations.

68 One example given is that of dwarf elephants that populated Mediterranean islands in prehistoric times. The initiation of a new trait (reduced size) occurred due to a famine that caused the elephants to atrophy, while the source of the "dwarf elephant" trait is natural selection that favored smaller elephants that were more easily sated. Cf. Roth (1992), "Inferences from allometry and fossils: Dwarfing of elephants on islands", in Futuyma \& Antonovics (eds.), Oxford Surveys in Evolutionary Biology, Oxford UP. 
genes, or development). It is in this context of redefining the process of selection that West-Eberhard introduced the notion of "developmental plasticity" that associates two terms of biological language, plasticity and development, used with specific meanings. West-Eberhard defines development as any phenotypic change during an individual's life or any other unit of higher organization and which also includes irreversible elements (such as muscle growth). Plasticity is defined as an organism's ability to react to an internal or external signal by a change in shape, state, movement, or activity level. This change may be adaptive or not, reversible or not, active or passive; it may vary continuously or not. The notion of "developmental plasticity" that results from the broadening of these two terms' meanings groups together into a single process phenomenon that biologists may have previously considered different. In the new definition, "phenotypic plasticity" appears as a particular instance of developmental plasticity. One of West-Eberhard's major contributions to the concept of phenotypic plasticity is her reinterpretation of the idea of phenotypic accommodation, ${ }^{69}$ which she defined as a form of adaptive adjustment among the phenotype's variable aspects, produced throughout development without genetic changes. The Dutch anatomist Everhard J. Slijper provides one example of such an accommodation. In 1942, he observed a goat that, at birth, only had two legs; the goat had reacted to this serous handicap by morphological and behavioral specializations that ultimately helped the goat to move around. ${ }^{70}$ For West-Eberhard, the important point here was that locomotive function had been preserved. In her view, adaptive accommodations that favor normal development (moving around, for example) have a higher probability of contributing to the appearance of a new functionality (here, a new mode of locomotion) that, though it may hardly be viable and

69 In 1945, Jean Piaget (La formation du symbole chez l'enfant, Delachaux \& Niestlé) defined phenotypic accommodation as the process by which an organism adapts itself to new surroundings, with this accommodation not being predetermined by the genetic system. For Piaget, this process could in certain cases pass back into this system, causing it to modify its predetermined ensemble of possible phenotypic constructions by introducing an adaptive transformation of hereditary material (a genotypic accommodation).

70 Slijper (1942), "Biologic-anatomical investigations on the bipedal gait and upright posture in mammals, with special reference to a little goat, born without forelegs", Proc. Koninklijke Nederlandse Akademie Van Wetenschappen, 45. This would later be called the "two-legged goat" effect. (Ndd.) 
compatible with the individual's genesis, can give rise to an increase in the frequency of the appearance of the initial trait (two legs instead of four), leading to the eventual production of a sub-population of individuals presenting the trait in question. This was the case for dwarf elephants in the Mediterranean. This process may be followed by a "genetic accommodation" that translates into a change in the genetic frequency that affects the regulation, form, or secondary effects of the new trait under the effect of the selection/variation process Darwin described.

Understanding phenotypic plasticity depends in large part on the type of questions that evolutionists ask. Four hierarchical levels of analysis exist: microevolution within populations, microevolution among populations, macroevolution at the species level, and macroevolution at the level of higher taxons. As the historical overview that I have just retraced here suggests, even if most of the attention has been paid to genes and to the evolution of genetic frequencies, research on phenotypic plasticity has led to new problems even as it has led well as to a greater understanding of its role in evolution. Sections 2 and 3 explore these two aspects in microevolution and in macroevolution, respectively.

\section{Phenotypic plasticity in microevolution (Problems and solutions)}

Microevolution $^{71}$ is defined as evolution that occurs below the level of species (the inverse of macroevolution) and, due to the success of population genetics, as the change in genetic frequencies within a population of organisms over time, or the process by which new species are created (speciation). ${ }^{72}$ Four processes are considered as being at the origin of this change: mutation, selection, gene transfer and

71 The term microevolution (just like the term macroevolution) was first used in English by Dobzhansky (1937, Genetics and the origin of species, Columbia UP). He defined microevolutionary changes as alterations that were "observable in the course of a human lifetime" in the composition of populations, as opposed to macroevolutionary changes "that required a temporality on the scale of geological time" (p. 12). For a discussion of the origins and meanings of these terms, cf. Arthur (2003), "Micro-, macro-, and megaevolution", in Hall \& Olson (eds.), Keywords \& concepts in evolutionary developmental biology, Harvard UP.

72 Cf. Samadi \& Barberousse's chapter, this volume. (Ndd.) 
genetic drift. ${ }^{73}$ Genetic variation (and its selection) is a satisfactory explanatory element for microevolution, since it lies at the origin of the causal chain leading to the production of new phenotypes; it is random, it is easy to follow its evolution via crossings, and it is easy to express it in mathematical terms. Hence, understanding the causal link between genetic variation and phenotypic variation of selection of the latter favorably or unfavorably provides a coherent and satisfactory image of evolution. Since the selected phenotype always carries its specific genetic alteration, evolution can be considered, in terms of population genetics, as a change in allelic frequency in populations over time.

Nevertheless, microevolution is more generally defined as all observable cases of evolution. The emergence of resistance factors to antibiotics in certain strains of bacteria or the change in color of moths over time, are just some examples. Such nuance suggests the possibility of other theories; though population genetics models the dynamic of changes in allelic frequencies, the correlation between these genetic changes and the phenotypic changes that would be associated with it are only assumed - population genetics does not actually demonstrate this. Clarifying the link between genetic variation and phenotypic variation provides more precision as to the type and amount of phenotypic variation that can be correlated to genetic variation. ${ }^{\mathbf{7 4}}$

Explaining microevolution requires a more precise understanding of the direct causes of phenotypic variation. From this perspective, research on phenotypic plasticity has provided a new approach to these questions.

\subsection{Microevolution within populations}

Within populations, two essential determinants of adaptive evolutionary processes have been identified: selection (and the environment that causes it) and constraints. The case of plants that will show more or less plasticity in response to the light's spectral quality, itself modulated by leaf shade, helps shed light on the link between

3 Cf. Heams («Variation »), Huneman («Sélection») in this volume.

74 For a discussion of the problem of phenotypic variation, cf. Kirschner et al. (2005), The plausibility of life: resolving Darwin's dilemma, Yale UP; Kirschner \& Gerhart (2010), "Facilited variation", in Pigliucci \& Müller (eds.), Evolution, the extended synthesis, MIT Press. 
plasticity and its determinants. Here, plasticity is effectively an indicator of the competition that exists between plants and that results from the phenomenon called "shade avoidance" ${ }^{75}$ The degree of plastic response is linked to the habitat in which the plants have evolved (less plasticity in shade-tolerant species and more plasticity in shade-intolerant species $^{76}$ ). Generally, in such case studies most of the analyses rely on measuring genetic variation and neglect the measurement of environmental variation, or environmental heterogeneity. The environment is considered to be a disruptive element in the analysis and biologists strive to limit its variability.

This aspect highlights the gaps in population genetics ${ }^{77}$ when it comes to explaining microevolution: its inability to broaden the range of possibilities without accounting for this environmental variability in which organisms exist, its specific neglect of the dynamic and historical components of the evolutionary process, and its application only to single states of equilibrium and to distributions in the stabilized state. Consequently, it is difficult to know whether the observed microevolution is the result of a simple change in allelic frequency or of its de correlation with an existing heterogeneous physical terrain where the population is located.

At this point it is again necessary to establish a conceptual distinction between two "types" of plasticity. The first would be a non adaptive plasticity without a genetic basis but which "would precede" the evolutionary process of natural selec$\operatorname{tion}^{78}$ (a phenomenon West-Eberhard describes ${ }^{79}$ ) and which would essentially depend on environmental variability. The second would be adaptive phenotypic plasticity, with a genetic basis and which would be the result of natural selection. In this conception, non adaptive plasticity can favor adaptive phenotypic plasticity, but adaptive phenotypic plasticity, as a specific character (under genetic control), is not

75 Pigliucci (2001), Phenotypic Plasticity: Beyond Nature and Nurture, Johns Hopkins University Press.

76 Bradshaw \& Hardwick (1989), "Evolution and stress: genotypic and phenotypic components", Biological Journal of the Linnean Society, 37, $\mathrm{n}^{\circ} 1-2$.

77 Richard Lewontin who had already demonstrated this in his 1974 work, The genetic basis of evolutionary change, Columbia UP.

78 Since it precedes the evolutionary process, it is distinct from non adaptive phenotypic plasticity which will be a phenotypic variability that is dependent on both the genetic and environmental factors, but which will not be selected by natural selection.

79 West-Eberhard (2003), Developmental plasticity and evolution, Oxford UP. 
the only reflection or result of non adaptive plasticity. Its expression also depends on genetic control.

By showing these two different conceptual types of plasticity, it is then possible to resolve the controversy Sara Via introduced that plasticity would not be a trait like any other, but rather an epiphenomenon of natural selection. In reality plasticity is both a trait like any other that can be selected (adaptive or non adaptive phenotypic plasticity), but it is also independent from genetic control (non adaptive plasticity). This independence can give the illusion that it is an epiphenomenon of natural selection even if it actually only precedes natural selection. In practice, it continues to be difficult to distinguish the phenotypic trait from its plasticity.

For example, a population's polymorphism can be due to the fact that one part of the population is in a given environment and another part is in another environmental site. The two populations will then acquire ecotype characteristics. ${ }^{80} \mathrm{But}$ this polymorphism can also be caused by the fact that most of the environmental heterogeneity exists on scales of a few centimeters to less than a meter. Thus, even at a given site, the population is subjected to a strong (non adaptive) plasticity that may or may not have cumulative effects on the plastic variation generated by changes in allelic frequency. Adaptive plasticity will show up at the population level, or at the organism level, that adopts morphological specificities (for instance, in the case of a single individual's different parts encountering distinct environments and reacting to it as a result). Some examples of this type of phenotypic plasticity are heterophylly, the production of super and supra-leaves in semi-aquatic plants, or the differentiation between shade leaves and light leaves on the same tree.

In order to gain a better understanding of microevolutionary models and processes at work within populations, it is necessary to establish a quantification of the

\footnotetext{
${ }^{80}$ According to Cohan (2006, "Towards a conceptual and operational union of bacterial systematics, ecology, and evolution", Philosophical Transactions of the Royal Society of London $B, 361$ ), the formal definition of an ecotype is "a group of bacteria that are ecologically similar to one another. More specifically, member organisms of an ecotype are so similar that an adaptive mutant (or an adaptive recombinant) from one ecotype can outcompete all other individuals from the same ecotype". In other words, the competition for resources is more intense within a given ecotype than it is among connected ecotypes, which allows these linked groups to coexist in a given habitat.
} 
selection pressures in natural conditions. Even if the quantitative study of natural selection has a well-established theoretical base, the database on phenotypic plasticity is in this regard rather sparse. Selection is particularly important though much more difficult to study in very heterogeneous conditions, especially in those favoring the evolution of adaptive phenotypic plasticity. Biologists have found it necessary to re-evaluate their quantification of selective pressures if they want to explain the evolution of phenotypic plasticity.

The other component an evolutionist needs to understand microevolution at this level is the type and extend of constraints that are essentially defined in population genetics by the limits of genetic covariance ${ }^{81}$ and which limit the population's response to selection pressures. The study of genetic variation in reaction norms in a population quantifies genetic constraints. ${ }^{\mathbf{8 2}}$ Another category of constraint is the one concerning the organism's genetic architecture. At this level, relationships between dominance, pleiotropy, and epistasis within and among these loci that can affect the trait's average (or adaptive plasticity) are taken into consideration. Besides these molecular constraints, there are also physical ones that the non adaptive phenotypic plasticity described earlier depends on. These constraints also have an important role in the description of microevolutionary processes.

\subsection{Microevolution among populations}

It is at the population level where we can see the effects of ancient episodes of selection and their interactions with constraints. In some ways, the observable trends in current variation among populations may be viewed as "fossilized" evidence of these populations' past, but relatively recent, microevolutionary history. ${ }^{83}$ Microevolution among populations is thus the result of processes that have just been described in the preceding section. The question, then, is one of knowing how much these

81 That is, by the limits in interactions between genotype and environment. Cf. Stearns (1989), "The evolutionary significance of phenotypic plasticity", BioScience, 39(7).

82 Scheiner \& Lyman (1989), "The genetics of phenotypic plasticity I. Heritability", Journal of Evolutionary Biology, 2(2).

83 Armbruster \& Schwaegerle (1996), "Causes of covariation of phenotypic traits among populations”, Journal of Evolutionary Biology, 9 (3). 
trends are the result of natural selection or of constraints? The notion of genetic correlation has long been considered the subject of central study in order to respond to this question. The study of traits' correlations has increased in evolutionary biology ever since population biologists became aware of genetic correlations ${ }^{\mathbf{8 4}}$ among different traits that could increase or slow down adaptive evolution (most notably of pleiotropy). ${ }^{85}$ Genetic correlations between two traits expressed in the same environment and genetic correlations between expressions of the same traits in two (or more) environments may indicate selection (in the case of functional correlations) or constraints (in the case of structural correlations). The study of constraints has itself been the subject of important debates in the modern theory of evolution. ${ }^{86}$

Recognizing plasticity has added two important dimensions to this debate. First is the fact that there are constraints linking the expression of a single trait to multiple

84 A genetic correlation is a correlation between any two phenotypic variances that are statistically associated with genetic differences between individuals (Pigliucci, 2005, "Evolution of Phenotypic Plasticity: Where Are We Going Now?", Trends in Ecology \& Evolution, 20(9)).

85 Lande (1982), "A quantitative genetic theory of life history evolution”, Ecology, 63(3). Cheverud et al. (1983), "Quantitative genetics of development: genetic correlations among age-specific trait values and the evolution of ontogeny", Evolution, 37(5). Burger \& Lynch (1995), "Evolution and extinction in a changing environment: a quantitativegenetic analysis", Evolution, 49(1). Etterson \& Shaw (2001), "Constraint to adaptive evolution in response to global warming", Science, 294(5540). Chevin et al. (2010), "Adaptation, Plasticity, and Extinction in a Changing Environment: Towards a Predictive Theory", PLoS Biol, 8(4). The latter adopt a new definition of phenotypic plasticity serving to characterize the direct influence of the environment on individual phenotypes via developmental mechanisms. For linear reaction norm, plasticity is measured by the line's slope.

86 Antonovics (1976), "The nature of limits to natural selection", Annals of the Missouri Botanical Garden, 63(2). Gould (1980), "The Evolutionary Biology of Constraint", Daedalus, 109(2). Maynard Smith et al. (1985), "Developmental Constraints and Evolution: A Perspective from the Mountain Lake Conference on Development and Evolution", The Quarterly Review of Biology, 60(3). Wagner \& Altenberg (1996), "Complex adaptations and the evolution of evolvability", Evolution, 50(3). Philipps (1998), "Genetic constraints at the metamorphic boundary: Morphological development in the wood frog, Rana sylvatica", Journal of Evolutionary Biology, 11(4). Armbruster et al. (1999), "Covariance and decoupling of floral and vegetative traits in nine Neotropical plants: a reevaluation of Berg's correlation-pleiades concept", American Journal of Botany, 86(1). Merila et al. (1999), "Evolution of morphological differences with moderate genetic correlations among traits as exemplified by two flycatcher species (Ficedula; Muscicapidae)", Biological Journal of the Linnean Society, 52(1). Hodin (2000), "Plasticity and constraints in development and evolution", Journal of Experimental Zoolology (Mol Dev Evol), 299. Pigliucci \& Kaplan (2000), "The fall and rise of Dr Pangloss : adaptationism and the Spandrels paper 20 years later", Trends in Ecology \& Evolution, 15(2). 
environments. This is another way of visualizing reaction norms by tracing the genotypic means of the expression of a single trait in an environment and then confronting it with genotypic means of the same trait's expression in another environment. This confrontation provides an inter-environmental genetic correlation for the studied trait. ${ }^{87}$ Although this is a convenient method for thinking of plasticity using quantitative genetics, Pigliucci, following Via, ${ }^{\mathbf{8}}$ points out that this modeling is limited by the fact that is it generally difficult to visualize two environments at the same time. In addition, it is also possible that the constraints themselves are plastic. ${ }^{89}$ This phenomenon helps demonstrate the importance of context when it comes to determining constraints and genetic correlations and the fact that if for a long time population genetics has considered it to be a matter constants, it is time to think about the determining factors at the origin of their plasticity.${ }^{90}$ Finally, and as was suggested at the beginning of this second section, there are reasons to doubt that genetic correlations are the final word on the subject of constraints and that they are useful beyond simple descriptive statistics about evolutionary quantitative genetics. Some research ${ }^{91}$ has attempted to demonstrate that it is not possible to infer the related genetic architecture based on an observed genetic correlation, since many different adjacent causal chains can generate the same correlated framework. ${ }^{92}$ This

87 For example, Andersson \& Shaw (1994), "Phenotypic plasticity in Crepis tectorum (Asteraceae): genetic correlations across light regimens", Heredity, 72; Hébert et al. (1994), "Genetic, phenotypic, and environmental correlations in black medic, Medicago lupudina L, grown in three different environments", Theoretical and Applied Genetics, 88.

${ }^{88}$ Pigliucci (2005), “Evolution of Phenotypic Plasticity: Where Are We Going Now?”, Trends in Ecology \& Evolution, 20(9). Via (1987), "Genetic constraints on the evolution of phenotypic plasticity", in Loeschcke (ed.), Genetic constraints on adaptive evolution, Springer-Verlag.

89 Pigliucci et al. (1995), "Reaction Norms of Arabidopsis. II. Response to Stress and Unordered Environmental Variation", Functional Ecology, 9(3).

90 Stearns et al. (1991), "The effects of phenotypic plasticity on genetic correlations", Trends in Ecology and Evolution, 6(4).

91 Houle (1991), "Genetic Covariance of Fitness Correlates: What Genetic Correlations are Made of and Why it Matters", Evolution, 45(3). Gromko (1995), "Unpredictability of Correlated Response to Selection: Pleiotropy and Sampling Interact", Evolution, 49(4).

92 For a discussion of causes and correlations in biology, cf. Shipley (2000), Cause and correlation in biology: a user's guide to path analysis, structural equations and causal inference, Cambridge UP. 
does not, however, mean that the study of genetic correlations is useless: the observed trends suggest causal hypotheses that may then be tested by experimental methods.

Microevolution within and among populations has long been a major part of the literature on plasticity. However, plasticity's place in macroevolution has only been the subject of recent research and constitutes a promising new area of study in the field.

\section{Phenotypic plasticity in macroevolution (problems and solutions)}

The meaning of "macroevolution" has often been the topic of polemics. It is used to describe evolution above the level of species and sometimes also as a synonym for speciation. It is possible to distinguish evolution that exists immediately above the level of species, which includes without being limited to speciation, from evolution on higher taxonomic levels, which is characterized by the appearance of many of the most baffling phenotypic novelties (wings in vertebrates, mandibles, tortoise shells, etc.) and by the placement of organization plans. ${ }^{93}$ We will look at each of these types of macroevolution respectively in parts 3.1 and 3.2 of this section.

In both cases, phenotypic plasticity can play a very important role since it explains the evolution of new phenotypes, the colonization of new niches, and helps explain certain speciation phenomena. This perspective has recently led to a modification in how we think about certain familiar macroevolutionary phenomena, such as preadaptation and mosaic evolution.

\subsection{Macroevolution above the species level}

In this case, biologists attempt to discover models of phenotypic differentiation within the species and to establish if, and to what extent, they are themselves linked to speciation events. ${ }^{94}$ For a long time the consensus set forth by the synthetic theory

93 Hall (1992), Evolutionary developmental biology, Chapman \& Hall. Zrzavy \& Stys (1997), "The basic body plan of arthropods: insights from evolutionary morphology and developmental biology", Journal of Evolutionary Biology, 10.

94 Speciation is the process by which one or more species are formed from a common ances- 
of evolution led biologists to believe that geographical isolation was necessary in order to explain speciation. Selection that favored extremes (disruptive selection) could not alone be sufficient to overcome the effects of interbreeding. ${ }^{95}$ However, recent research ${ }^{96}$ suggests that phenotypic plasticity (intra-species variation) or the variation directed by developmental switches ${ }^{97}$ could lead to speciation phenomena and, eventually, to allopatric ${ }^{98}$ or sympatric ${ }^{99}$ divergence. West-Eberhard has suggested the "developmental plasticity hypothesis of speciation". According to this hypothesis, differences between alternative phenotypes (within the same species) may contribute to an evolution toward reproductive isolation. For example, some dimorphisms, such as those present in moths, show up as a type of normal abdominal segmentation versus a "phoretic" type with reduced segments, may be fixed either by natural selection or chance, and lead (via sexual selection) to a reproductive isolation. West-Eberhard calls this process "phenotypic fixation".

More generally, and before West-Eberhard, certain biologists considered plasticity a major initiator (and sometimes the only one) of macroevolutionary changes. ${ }^{100}$

For instance, plastic reaction norms may allow a population to survive in temporary situations of stress (as in the case of island dwarf elephants). Plasticity can

tor. Cf. Coyne (1992), “Genetics and speciation”, Nature, 355(6360); Grant (1994), “Evolution of the species concept", Biologisches Zentralblatt, 113.

95 Plutynski (2010), "Speciation and macroevolution", in Sarkar \& Plutynski (eds.), A Companion to the Philosophy of Biology, John Wiley and Sons, chap. 10.

96 West-Eberhard (2005), "Phenotypic accommodation: adaptive innovation due to developmental plasticity", Journal of Experimental Zoology Part B: Molecular and Developmental Evolution, 304B(6).

97 These are elements that, in the course of development, will allow the organism to move toward one developmental path over another (at the cellular level, these developmental switches will allow cells to be oriented toward one path of differentiation over another). In this mode of speciation, populations that can initially crossbreed evolve into distinct species because they are geographically isolated. This is by far the most common mode of speciation in animals.

99 Some populations that are not geographically isolated can evolve into distinct species. Here, natural selection plays a crucial role in populations' divergence.

${ }^{100}$ For example, Leclaire \& Brandle (1994), "Phenotypic plasticity and nutrition in a phytophagous insect: consequences of colonizing a new host”, Oecologia, 100(4); Gerhard \& Kirschner (1997), Cells, embryos, and evolution : toward a cellular and developmental understanding of phenotypic variation and evolutionary adaptability, Blackwell Science; Pigliucci (2001), Phenotypic Plasticity, op. cit. 
also allow a population to be maintained in new environmental conditions, leaving more time for mutations, recombination and selection to appear, permitting the population's level of adaptation to be more precise. Variation in a population's reaction norms can also slow down selection (stasis ${ }^{101}$ ) if the model of the genotype's interaction with the environment is such that the reaction norms of different genotypes produce similar phenotypes under normal environmental conditions. Inversely, this variation in a population's reaction norms can also accelerate selection (punctuated evolution) if the environmental range is such that different genotypes' reaction norms produce extremely different phenotypes.

These different examples indicate the importance of phenotypic plasticity as a way to explain certain speciation phenomena, but phenotypic plasticity's role can also be quite important for the generation of phenotypic novelties, and thus on a slightly higher macroevolutionary level.

\subsection{Macroevolution on higher taxonomic levels and the appearance of phe- notypic novelties}

Beyond the theoretical reasons, there are practical ones that lead to the distinction between macro and microevolution. Microevolution can be studied in the laboratory or in the field using comparative or experimental observation methods on individuals and populations, and for a limited number of generations. The known genetic properties and established ecological conditions are then used to interpret microevolution. Studies on macroevolution, though, are focused on differences within a species by working on a precise description of the species in question, by characterizing clades, and by establishing studies on phylogenetic relationships among taxa. Envi-

101 The theory of "punctuated equilibria" is an evolutionary biology theory that postulates that evolution includes long periods of equilibrium (stasis), or quasi-equilibrium, punctuated by brief periods of important changes such as speciation or extinctions. According to this theory, morphological evolution of species would be produced by very slow and continuous modifications within a population over the course of time by the interplay of mutations and natural selection. Cf. Eldredge \& Gould (1972), "Punctuated equilibria: an alternative to phyletic gradualism", in Schopf (ed.), Models in Paleobiology, Freeman Cooper. 
ronmental factors and genetic properties that influence speciation and extinction are generally difficult to infer.

As Paul Doughty and David Reznick ${ }^{102}$ point out, on a practical level, the scope of phenotypic difference among taxa is generally substantial enough for systematicians and paleontologists to choose to ignore sources of variation that are environmental in their analyses of phylogenies and macroevolutionary models of traits' evolution. Yet although it is possible to demonstrate that the environment influences phenotypic expression, it still gives no indication as to the adaptive character of the phenotypic response and it does not explain whether this response results from natural selection or if it is just the reflection of the environment's variation on the phenotype. ${ }^{103}$

Still, recent research looking at plasticity using a new evolutionary synthesis associating evolution and development (Evo-Devo) has once again helped connect microevolution with macroevolution. ${ }^{104} \mathrm{~A}$ growing number of biologists are working to demonstrate phenotypic plasticity's major role in the diversification of taxa. Schlichting has pointed out three distinct fields where plasticity plays a role in evolutionary change. First, phenotypic plasticity favors the production of alternative phenotypes, opening the way to genetic differentiation that can lead to the occupation of new ecological niches. It then promotes the maintenance of genetic diversity by reducing the impact of natural selection. And finally, it helps improve long-term survival of taxa via species selection. ${ }^{105}$

102 Doughty \& Reznick (2004), "Patterns and analysis of phenotypic plasticity in animals", in DeWitt \& Scheiner (eds.), Phenotypic plasticity: functional and conceptual approaches, Oxford UP.

${ }^{103}$ For example, Smith-Gill (1983), "Developmental Plasticity: Developmental Conversion versus Phenotypic Modulation”, American Zoologist, 23(1); Stearns (1989), “The evolutionary significance of phenotypic plasticity", BioScience, 39(7); Newman (1992), "Adaptive Plasticity in Amphibian Metamorphosis", BioScience, 42(9); Doughty (1995), "Testing the ecological correlates of phenotypically plastic traits within a phylogenetic framework", Acta Ecologica, 16.

${ }^{104}$ Kirschner et al. (2005), The plausibility of life: resolving Darwin's dilemma, Yale UP.

${ }^{105}$ Schlichting (2004), "The role of phenotypic plasticity in diversification", in DeWitt \& Scheiner (eds.), Phenotypic plasticity: functional and conceptual approaches, Oxford UP. 
In 2010, Pigliucci summarized the main reasons that make phenotypic plasticity an important avenue of research in macroevolution. The phenotypic and genetic accommodation (and the evolution of its understanding from Baldwin to West-Eberhard) could progressively be considered as a major explanation behind the well-known phenomenon of mosaic evolution. ${ }^{106}$ Even if it were possible to

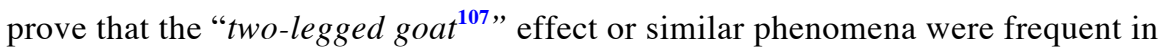
nature, the appearance of a mosaic evolution would nevertheless persist, as Pigliucci ${ }^{108}$ has pointed out, as it does in the fossil archives. This appearance exists even when most of the observed phenotypic changes had taken place simultaneously due to the inherent plasticity in developmental systems. On the other hand, phenotypic plasticity can also shed new light on the way pre-adaptations ${ }^{109}$ occur. Since most new environments generally correlate to ancient ones, it is likely that the variation of phenotypic plasticity in a given population includes reaction norms that will be applied - at least-sub-optimally to the new environment (or to the new function). This is what Baldwin calls organic selection. ${ }^{110}$

West-Eberhard ${ }^{111}$ has also for some time advocated the role of behavioral plasticity in macroevolution. She points out, repeatedly, ${ }^{112}$ how behavior constitutes a major mechanism in the formation and appearance of new morphological traits. This

106 The classic definition of mosaic evolution is "Evolution of different characters at different rates within a lineage. [...] It is one of the most important principles of evolution, for it says that a species evolves not as a whole, but piecemeal: many of its features evolve quasi-independently".(Futuyma, 1998, Evolutionary biology, Sinauer Associates).

${ }^{107}$ Cf. note 70 . (Ndd.)

${ }^{108}$ Pigliucci (2010), "Phenotypic plasticity", in Pigliucci \& Müller (eds.), Evolution, the extended synthesis, MIT Press.

${ }^{109}$ Futuyma (1998, op. cit.) defines preadaptation as the "Possession of the necessary properties to permit a shift to a new niche, habitat, or function. A structure is preadapted for a new function if it can assume that function without evolutionary modification". [Cf. section 3 of Grandcolas's chapter, "Adaptation" this volume. (Ndd.)]

${ }^{110}$ Cf. note 21. (Ndd.)

${ }^{111}$ West-Eberhard (1989), "Phenotypic Plasticity and the Origins of Diversity", Annual Review of Ecology and Systematics, 20; idem (2005), "Phenotypic accommodation: adaptive innovation due to developmental plasticity", Journal of Experimental Zoology Part B, 304B(6).

112 West-Eberhard (1989), "Phenotypic Plasticity...," op. cit. ; idem (2003), Developmental plasticity and evolution, Oxford UP; idem (2005), "Phenotypic accommodation...", op. cit. 
perspective can be broadened when phenotypic plasticity is considered as a generalized equivalent of behavior. ${ }^{113}$ Phenotypic plasticity can also be considered a major actor in the process of niche construction, ${ }^{114}$ even though this concept remains controversial. ${ }^{115}$

\section{Conclusions}

Two conclusions arise out of this study of phenotypic plasticity in evolution. The first concerns the concept itself and its understanding in evolutionary biology. The second specifically concerns the role of phenotypic plasticity as a scientific tool of evolutionary biology.

\subsection{Phenotypic plasticity: a unique plasticity?}

As the first part of this study demonstrated, even if the notion of "plasticity" is ancient (its use going back to Platonist philosophers of the seventeenth century or two centuries later to Darwin's use of the concept in evolutionary biology), the notion of "phenotypic plasticity" is, for its part, relatively recent. ${ }^{116}$ This newer term refers to organisms' ongoing capacity for adaptation to environmental variations via the development of alternative phenotypes. The notion of phenotypic plasticity is, then, at its root intimately correlated to the distinction Wilhelm Johannsen first showed in 1911 between genotype and phenotype in order to highlight the difference between an organism's hereditary factors (its genes) and their effects (phenotypes). Phenotypic plasticity is thus above all a result (explanandum) more than a cause (explanans) of variation in life (this variation being limited from the beginning to genetic

${ }^{113}$ This is the case for many researchers; for example Mayley (1996), "Landscapes, Learning Costs, and Genetic Assimilation”, Evolutionary Computation, 4(3); Novoplansky (2002), "Developmental plasticity in plants: implications of non-cognitive behaviour", Evolutionary Ecology, 16(3) ; Paenke et al. (2007), "Influence of plasticity and learning on evolution under directional selection", American Naturalist, 170(2).

${ }^{114}$ Odling-Smee et al. (2003), Niche construction: the neglected process in evolution, Princeton UP. Okasha (2005), Evolution and the levels of selection, Oxford UP. Laland \& Sterelny (2006), "Seven reasons (not) to neglect niche construction", Evolution, 60.

${ }^{115} \mathrm{Cf}$. Pocheville, this volume.

${ }^{116}$ Nilsson-Ehle (1914), "Vilka erfarenheter hava hittills vunnits rörande möjligheten av växters acklimatisering”, Kunglig Landtbruks-Akaemiens. Handlinger och Tidskrift, 53. 
variation). If this reasoning holds, it becomes logical for some biologists to consider plasticity to be a trait like any other and therefore to research its genetic basis. This is the perspective taken in the polynomial approach to plasticity. ${ }^{117}$

However, this framework is upended when the linear relationship between genotype and phenotype is challenged, and if the environment is also considered to be an inheritable factor. ${ }^{118}$ Phenotypic plasticity's status must then be redefined. Sara Via has shown, counter to the polynomial approach, that phenotypic plasticity could be more of a secondary effect of natural selection. ${ }^{119}$ This first controversy around the notion's status quickly revealed itself to be based on semantics, ${ }^{120}$ and researchers attempted to resolve it by redefining the term and increasing the confusion. ${ }^{121}$ Mary Jane West-Eberhard ${ }^{122}$ finally suggested that even if phenotypic plasticity must not be considerd as a simple effect of genic expression, then on the contrary it would precede genic fixation. Such clear indecision as to phenotypic plasticity's status as either an explanans or an explanandum, which also reflects the diversity of its ancient meanings, remains a source of confusion in the field of evolutionary biology. For this reason, the distinction between a concept of "non adaptative plasticity" as an explanans and a concept of "phenotypic plasticity" as an explanadum may provide a resolution to the semantic confusion while still preserving the notion of "phenotypic plasticity" inherent in the historic concept of phenotype as Johannsen imagined it.

\subsection{Phenotypic plasticity in evolutionary biology}

${ }^{117}$ Van Tienderen (1991), "Evolution of Generalists and Specialist in Spatially Heterogeneous Environments", Evolution, 45(6). Scheiner (1993), "Genetics and Evolution of Phenotypic Plasticity", Annual Review of Ecology and Systematics, 24(1).

118 Gilbert \& Epel (2009), Ecological Developmental Biology: Integrating Epigenetics, Medicine, and Evolution, Sinauer Associates.

${ }^{119}$ Via (1993), "Adaptive Phenotypic Plasticity: Target or By-Product of Selection in a Variable Environment?", The American Naturalist, 142(2).

${ }^{120}$ Schlichting \& Pigliucci (1993), "Control of Phenotypic Plasticity Via Regulatory Genes", The American Naturalist, 142(2).

${ }^{121}$ For a discussion of some different interpretations of the notion of plasticity in biology, cf. Nicoglou (forthcoming), "Defining the boundaries of development with plasticity", Biological Theory, 6(1).

${ }^{122}$ West-Eberhard (2003), Developmental plasticity and evolution, Oxford UP. 
Phenotypic plasticity is central to the study of many aspects of evolutionary biology for the simple reason that organisms develop in specific environments and that these environments are often labile over short periods and on a weak scale. Examples of fields where the genotype-environment interaction can play a pivotal role in future research include adaptogenesis, ${ }^{123}$ the problem of maintaining genetic variation in natural populations, quantitative genetics, the modeling of evolutionary trajectories, the study of character correlations and constraints, the evolution of genetic regulation, comparative phylogenetic research on evolutionary adaptation, or the study of macroevolution (whether of speciation phenomena or of larger-scale macroevolution).

The diversity and numerous examples for which phenotypic plasticity may play a key role are clear evidence of this topic's importance for the understanding of the mechanisms at work in evolutionary biology.

Recent studies at the cellular and molecular levels have shown more recently that phenotypic plasticity (enzyme reaction curves) could play are major role in understanding the evolution of development, especially when the internal environment to which cells are exposed changes. The study of these phenomena could lead to an understanding of how the evolution of differentiation in multi-celled organisms might have begun. ${ }^{124}$

Finally, plasticity should probably be considered as living systems' (organisms as a group or as their components) state by default; their biomolecules' physicalchemical properties tend to alter their general properties when certain aspects of the environment change. As a result, any absence of plasticity (homeostasis) must be considered as having undergone the effect of canalizing selection and is probably the result of an adaptation. ${ }^{125}$

${ }^{123}$ The study of the origin of adaptations.

124 Newman \& Bhat (2009), "Dynamical patterning modules a 'pattern language' for development and evolution of multicellular form", International Journal of Developmental Biology, 53.

${ }^{125}$ I would like to thank Jean Gayon, Philippe Huneman \& Marc Silberstein. 
Bibliographical references

\section{A}

ANDERSON S.\& SHAW R.G. (1994), "phenotypic plasticity in Crepis tectorum

(Asteraceae): genetic correlations across light regimens", Heredity, 72: 113-125.

ANTONOVICS J. (1976), "The nature of limits to natural selection", Annals of the Missouri Botanical Garden: 224-247.

ARMBRUSTER W.S. \& SCHWAELERLE K.E. (1996), “Causes of covariation of phenotypic traits among populations", Journal of Evolutionary Biology, 9 (3): 261-276.

ARMbruster W.S., Di STILIO V.S., TUXILl J.D., FLORES T.C. \& VELASQUEZ RUNK J.L. (1999), "Covariance and decoupling of floral and vegetative traits in nine Neotropical plants: a re-evaluation of Berg's correlation-pleiades concept", American Journal of Botany, 86(1) : 39-55.

ARTHUR W. (2003), "Micro-, macro-, and megaevolution", in B.K. Hall \& W.M. Olson (eds.), Keywords \& concepts in evolutionary developmental biology, Cambridge Mass., Harvard University Press.

AubIN-HoRTH N. \& RENN C.P. (2009), "Genomic reaction norms: using integrative biology to understand molecular mechanisms of phenotypic plasticity", Molecular Ecology, 18(18): 3763-3780.

$\mathrm{B}$

BADYAEV A.V. (2005), "Stress-induced variation in evolution: from behavioural plasticity to genetic assimilation", Proceedings of the Royal Society B: Biological Sciences, 272(1566): 877 -886.

BALDWIN J.M. (1896), “A New Factor in Evolution”, American Naturalist, 30: 441451.

Ballaré C.L. (1999), "Keeping up with the neighbours: phytochrome sensing and other signalling mechanisms", Trends in plant science, 4(3): 97-102.

BARTON N.H. \& TURELli M. (1989), "Evolutionary Quantitative Genetics: How Little Do We Know ?", Annual Review of Genetics, 23(1): 337-370.

BRADSHAW A.D. (1965) "Evolutionary significance of phenotypic plasticity in plants", Advances in Genetics, 13: 115-155.

BRADSHAW A.D \& HARDWICK K. (1989), "Evolution and stress: genotypic and phenotypic components", Biological Journal of the Linnean Society 37, $\mathrm{n}^{\circ} 1-2$ : 137-155.

BURGER R. \& LYNCH M. (1995), "Evolution and extinction in a changing environment: a quantitative-genetic analysis", Evolution, 49(1): 151-163.

C

Callahan H.S., Pigliucci M. \& Schlichting C.D. (1997), "Developmental phenotypic plasticity: where ecology and evolution meet molecular biology", $B i$ oEssays, 19(6): 519-525.

CheVERUd J.M., RutLEDGE J.J. \& ATCHLEY W.R. (1983), “Quantitative genetics of development: genetic correlations among age-specific trait values and the evolution of ontogeny", Evolution, 37(5): 895-905. 
Chevin LM., LANDe R. \& MACE G.M. (2010), “Adaptation, Plasticity, and Extinction in a Changing Environment: Towards a Predictive Theory", PLoS Biol, 8(4).

COHAN F.M. (2006), "Towards a conceptual and operational union of bacterial systematics, ecology, and evolution, Philosophical Transactions of the Royal Society of London B, 361: 1985-1996.

COYNE J.A. (1992), “Genetics and speciation”, Nature, 355(6360): 511-515.

CRESPI E.J. \& DENVER R.J. (2005), "Roles of stress hormones in food intake regulation in anuran amphibians throughout the life cycle", Comparative Biochemistry and Physiology-Part A: Molecular \& Integrative Physiology, 141(4): 381-390.

CUDWORTH R. (1678), The True Intellectual System of the Universe, London, Richard Royston.

D

DARWIN C. (1872), The origin of species by means of natural selection, or the preservation of favoured races in the struggle for life, London, John Murray, 6th ed.

DARWIN C. (1875), The Variation of Animals and Plants Under Domestication, Londres, John Murray, $2^{\text {nd }}$ ed., volume 2.

DE JONG G. (1995), "Phenotypic Plasticity as a Product of Selection in a Variable Environment", The American Naturalist, 145(4): 493-512.

DesCARTES R. (1641), Méditations métaphysiques, 3ème édition, Paris, Michel Bobin et Nicolas le Gras, 1673.

DOBZHANSKY T. (1951), Genetics and the origin of species [1937], Columbia, Columbia University Press.

DOBZHANSKY T. (1955), Evolution, genetics, and man, New York, John Wiley and Sons.

Doughty P. (1995), "Testing the ecological correlates of phenotypically plastic traits within a phylogenetic framework", Acta Oecologica, 16: 519-524.

Doughty P. \& REZNICK D. (2004), "Patterns and analysis of phenotypic plasticity in animals", in T.J. DeWitt \& S.M. Scheiner (eds.), Phenotypic plasticity: functional and conceptual approaches, Oxford, Oxford University Press: 126-150.

DuCHESNEAU F. (1998), Les modèles du vivant de Descartes à Leibniz, Paris, Vrin.

E

ELDREDGE N. \& Gould S.J. (1972), "Punctuated equilibria: an alternative to phyletic gradualism”, in T.J.M. Schopf (ed.), Models in Paleobiology, San Francisco, Freeman Cooper : 82-115. Reprinted in N. Eldredge, Time frames, Princeton, Princeton University Press, 1985: 193-223.

ETTERSON J.R. \& SHAW R.G. (2001), “Constraint to adaptive evolution in response to global warming", Science, 294(5540): 151.

F

FALCONER D.S. (1952), “The Problem of Environment and Selection”, The American Naturalist, 86(830): 293-298.

FALCONER D.S. (1981), Introduction to quantitative genetics, New York, Longman. 
FISHER R.A. (1930), The genetical theory of natural selection, Oxford, Clarendon Press.

FRIML J. \& SAUER M. (2008), "Plant biology: in their neighbour's shadow", Nature, 453(7193): 298-299.

FutuYAMA D.J. (1998), Evolutionary biology, Sunderland (Mass.), Sinauer Associates.

G

GAuse G.F. (1947), "Problems of Evolution", Transaction of the Connecticut Academy of Sciences, 37: 17-68.

GERHARD J. \& KIRSCHNER M. (1997), Cells, embryos, and evolution: toward a cellular and developmental understanding of phenotypic variation and evolutionary adaptability, Oxford, Blackwell Science.

GILBERT S. \& EPEL D. (2009), Ecological Developmental Biology: Integrating Epigenetics, Medicine, and Evolution, Sunderland (Mass.), Sinauer Associates.

GILLESPIE J.H. \& TURELLI M. (1989), "Genotype-Environment Interactions and the Maintenance of Polygenic Variation”, Genetics 121(1): 129-138.

Godin C. (2004), Dictionnaire de Philosophie, Paris, Fayard/éditions du temps.

Gould S.J. (1980), “The Evolutionary Biology of Constraint”, Daedalus 109(2): 39-52.

GRANT V. (1994), "Evolution of the species concept", Biologisches Zentralblatt, 113: 401-415.

Gromko M.H. (1995), "Unpredictability of Correlated Response to Selection: Pleiotropy and Sampling Interact", Evolution, 49(4): 685-693.

$\mathrm{H}$

HaLl B.K. (1992), Evolutionary developmental biology, London, Chapman \& Hall.

Hebert D., FAure S . \& OliviERI I. (1994), "Genetic, phenotypic, and environmental correlations in black medic, Medicago lupudina $L$, grown in three different environments", Theoretical and Applied Genetics, 88: 604-613.

HodiN J. (2000), "Plasticity and constraints in development and evolution", Journal of Experimental Zoolology (Mol Dev Evol) 299: 1-20.

HoGBEN L. T. (1939), Nature and nurture, Birmingham, University of Birmingham, Faculty of Medicine, William Withering memorial lectureship, G. Allen \& Unwin, Ltd.

Houle D. (1991), “Genetic Covariance of Fitness Correlates: What Genetic Correlations are Made of and Why it Matters", Evolution, 45(3): 630-648.

$\mathrm{J}$

JINKS J.L. \& POONI H.S. (1988), The genetic basis of environmental sensitivity, Sunderland, Mass. (USA), Sinauer Associates.

JOHANNSEN W.A. (1911), "The genotype conception of heredity", American Naturalist, 45: 129-159.

$\mathrm{K}$ 
KAPLAN J.M. \& PigLIUCCI M. (2001), “Genes 'for' phenotypes: a modern history view”, Biology and Philosophy, 16(2): 189-213.

KIRSCHNER M.W. \& GERHART J.C. (2010), "Facilited variation”, in M. Pigliucci \& G.B. Müller (eds.), Evolution, the extended synthesis, Cambridge (Mass.), MIT Press.

KIRSCHNER M.W., GERHART J.C. \& NORTON J. (2005), The plausibility of life: resolving Darwin's dilemma, New-York, Yale University Press.

L

LALAND K.N. \& STERELNY K. (2006), "Seven reasons (not) to neglect niche construction”, Evolution, 60: 1751-1762.

LAMARCK J-B. (1809), Philosophie zoologique, Paris, Dentu.

LANDE R. (1980), "Genetic Variation and Phenotypic Evolution During Allopatric Speciation", The American Naturalist, 116 (4): 463-479.

LANDE R. (1982), “A quantitative genetic theory of life history evolution”, Ecology, 63(3): 607-615.

LANDE R. \& ARNOLD S.J. (1983), “The measurement of selection on correlated characters", Evolution, 37(6) : 1210-1226.

LECLAIRE M. \& BRANDLE R. (1994), "Phenotypic plasticity and nutrition in a phytophagous insect: consequences of colonizing a new host", Oecologia, 100(4) : 379-385.

LERNER I. M. (1954), Genetic homeostasis, Oxford, John Wiley and Sons.

LEWONTIN R.C. (1974), The genetic basis of evolutionary change, Columbia, Columbia University Press.

Lloyd MORGAN C. (1900), Animal behavior, London, E. Arnold.

LYNCH M. \& GABRIEL W. (1987), "Environmental Tolerance”, The American Naturalist, 129(2): 283-303.

$\mathrm{M}$

MAYLEy G. (1996), "Landscapes, Learning Costs, and Genetic Assimilation”, Evolutionary Computation, 4(3): 213-234.

MAYNARD SMITH J. (1990), "Models of a dual inheritance system”, Journal of Theoretical Biology, 143(1): 41-53.

Maynard Smith J., Burian R., KaufFMan S., Alberch P., CAMPBell J., GoodWIN B., LANDE R., RAUP D. \& WOLPERT L. (1985), “Developmental Constraints and Evolution: A Perspective from the Mountain Lake Conference on Development and Evolution", The Quarterly Review of Biology, 60(3): 265-287.

MERILA J., BJORKLUND M. \& GUSTAFSSON L. (1999), "Evolution of morphological differences with moderate genetic correlations among traits as exemplified by two flycatcher species (Ficedula; Muscicapidae)", Biological Journal of the Linnean Society, 52(1): 19-30.

MORE H. (2011), The immortality of the soul, so far as it is demonstrable from the knowledge of nature and the light of reason [1659], London, Proquest (Eebo Editions). 
$\mathrm{N}$

NeWMan R.A (1992), “Adaptive Plasticity in Amphibian Metamorphosis”, BioScience, 42(9): 671-678.

NEWMAN S.A. \& BHAT R. (2009), "Dynamical patterning modules: a "pattern language' for development and evolution of multicellular form", International Journal of Developmental Biology, 53: 693-705.

NiCOGlou A. (2011), « Expliquer la forme », Critique, 764-765: 119-129.

NiCOGLOU A. (2011), "Defining the boundaries of development with plasticity", Biological Theory, 6(1): 36-47.

Nishout H. F. (2003) "Development and Evolution of Adaptive Polyphenisms", Evolution and Development, 5(1): 9-18.

NILSSON-EHLE H. (1914), "Vilka erfarenheter hava hittills vunnits rörande möjligheten av växters acklimatisering”, Kunglig Landtbruks-Akaemiens. Handlinger och Tidskrift, 53: 537-572.

NOVOPLANSKY A. (2002) "Developmental plasticity in plants: implications of noncognitive behaviour”, Evolutionary Ecology, 16(3): 177-188.

$\mathrm{O}$

OdLING-SMEE F.J., LALAND K.N. \& FELDMAN M.W. (2003), Niche construction: the neglected process in evolution, Princeton, Princeton University Press.

OKASHA S. (2005), Evolution and the levels of selection, Oxford, Oxford University Press.

OSBORN H.F. (1897), “The Limits of Organic Selection”, American Naturalist, 31 : 944-951.

$\mathrm{P}$

PAENKE I., SENDHOFF B. \& KAWECKi T.J. (2007), "Influence of plasticity and learning on evolution under directional selection", American Naturalist, 170(2): 1-12.

PHILIPPS P.C. (1998), "Genetic constraints at the metamorphic boundary: Morphological development in the wood frog, Rana sylvatica", Journal of Evolutionary Biology, 11(4): 453-463.

PiAgET J. (1945), La formation du symbole chez l'enfant, Neuchâtel et Paris, Delachaux \& Niestlé.

Pigliucci M. (2001), Phenotypic Plasticity: Beyond Nature and Nurture, Baltimore, Johns Hopkins University Press.

PigliucCi M. (2005), "Evolution of Phenotypic Plasticity: Where Are We Going Now ?", Trends in Ecology \& Evolution 20(9) : 481-486.

Pigliucci M. (2010), "Phenotypic plasticity", in M. Pigliucci \& G.B. Müller (eds.), Evolution, the extended synthesis, Cambridge (Mass.), MIT Press.

PigliuCCI M. \& KAPLAN J. (2000), “The fall and rise of Dr Pangloss: adaptationism and the Spandrels paper 20 years later", Trends in Ecology \& Evolution, 15(2): 66-70.

Pigliucci M., Schlichting C.D. \& WhitTon J. (1995), "Reaction Norms of Arabidopsis. II. Response to Stress and Unordered Environmental Variation", Functional Ecology, 9(3): 537-547. 
PlUTYNSKI A. (2010) "Speciation and macroevolution", in S. Sarkar \& A. Plutynski (eds.), A Companion to the Philosophy of Biology, Oxford, John Wiley and Sons.

$\mathrm{R}$

RoFF D.A. (1997), Evolutionary quantitative genetics, New York, Chapman \& Hall. RoMASCHOFF D.D. (1925), "Über die Variabilität in der Manifestierung eines erblichen Merkmales (Abdomen abnormalis) bei Drosophila funebris F", Journal für Psychologie und Neurologie, 31: 323-325.

ROTH V.L (1992), "Inferences from allometry and fossils: Dwarfing of elephants on islands", in D. Futuyma \& J. Antonovics (eds.), Oxford Surveys in Evolutionary Biology, vol. 8, Oxford, Oxford University Press: 259-288.

$\mathrm{S}$

SARKAR S. (1999), "From the Reaktionsnorm to the adaptive norm: The reaction Norm, 1909-1960”, Biology and Philosophy, 14: 235-252.

SCHEINER S.M. (1993), "Genetics and Evolution of Phenotypic Plasticity", Annual Review of Ecology and Systematics, 24(1): 35-68.

SCHEINER S.M. \& LYMAN R.F. (1989), "The genetics of phenotypic plasticity I. Heritability”, Journal of Evolutionary Biology, 2(2): 95-107.

SCHEINER S.M. \& LYMAN R.F. (1991), "The genetics of phenotypic plasticity. II. Response to selection", Journal of Evolutionary Biology, 4(1): 23-50.

SCHLICHTING C.D. (2004), "The role of phenotypic plasticity in diversification", in T.J. DeWitt \& S.M. Scheiner, Phenotypic plasticity: functional and conceptual approaches, Oxford, Oxford University Press.

SCHLICHTING C.D. (1986), "The evolution of phenotypic plasticity in plants", Annual Review of Ecology, Evolution and Systematics, 17: 667-693.

SChlichting C.D. \& Pigliucci M. (1993), "Control of Phenotypic Plasticity Via Regulatory Genes”, The American Naturalist, 142(2): 366-370.

SCHMALHAUSEN I.I. (1986), Factors of evolution: the theory of stabilizing selection [1949], Chicago, University of Chicago Press.

SCHMiTT J.A. MCCCORMAC C. \& SMITH H. (1995), “A test of the adaptive plasticity hypothesis using transgenic and mutant plants disabled in phytochrome-mediated elongation responses to neighbors", American Naturalist, 146(6): 937-953.

SHAw F.H., SHAW R.G., WiLKInSON G.S. \& TURELli M. (1995), "Changes in Genetic Variances and Covariances: G Whiz!", Evolution, 49(6) : 1260-1267.

SHIPLEY B. (2000), Cause and correlation in biology: a user's guide to path analysis, structural equations and causal inference, Cambridge, Cambridge University Press.

SLATKIN M. (1987), "Quantitative genetics of heterochrony”, Evolution 41(4): 799811.

SMITH H. (1990), "Signal perception, differential expression within multigene families and the molecular basis of phenotypic plasticity", Plant, Cell \& Environment, 13(7): 585-594.

SMITH-GILl S.J. (1983), "Developmental Plasticity: Developmental Conversion versus Phenotypic Modulation”, American Zoologist, 23(1) : 47 -55. 
STEARNS S.C., DE JONG G. \& NEWMAN B . (1991), "The effects of phenotypic plasticity on genetic correlations", Trends in Ecology and Evolution, 6(4): 122-126.

STEARNS S.C. (1989), "The evolutionary significance of phenotypic plasticity", BioScience, 39(7): 436-445.

\section{$\mathrm{T}$}

TIMOFÉEFF-RESSOVSKY H.A. \& TIMOFÉEFF-RESSOVSKY N.W. (1926), "Über das phänotypische Manifestation des Genotypes. II. Über idio-somatische Variationsgruppen bei Drosophila funebris, Wilhelm Roux", Archiv für Entwicklungsmechanik der Organismen, 108: 146-170.

$\mathrm{V}$

VAN TIENDEREN P.H. (1991), "Evolution of Generalists and Specialist in Spatially Heterogeneous Environments", Evolution, 45(6): 1317-1331.

VAN TIENDEREN P.H. \& KOELEWIJN H.P. (1994), "Selection on Reaction Norms, Genetic Correlations and Constraints", Genetics Research, 64(2): 115-125.

VAN TIENDEREN P.H., HAMMAD I. \& ZWAAL F.C. (1996), "Pleiotropic Effects of Flowering Time Genes in the Annual Crucifer Arabidopsis thaliana (Brassicaceae)", American Journal of Botany, 83(2): 169-174.

VIA S. (1984), "The Quantitative Genetics of Polyphagy in an Insect Herbivore. II. Genetic Correlations in Larval Performance Within and Among Host Plants", Evolution, 38(4): 896-905.

VIA S. (1987), "Genetic constraints on the evolution of phenotypic plasticity", in V. Loeschcke (ed.), Genetic constraints on Adaptive evolution, Berlin, SpringerVerlag: 47-71.

VIA S. (1993), “Adaptive Phenotypic Plasticity: Target or By-Product of Selection in a Variable Environment?", The American Naturalist, 142(2): 352-365.

VIA S.\& LANDE R. (1985), "Genotype-environment interaction and the evolution of phenotypic plasticity", Evolution, 39: 505-522.

VIA S. \& LANDE R. (1987), "Evolution of Genetic Variability in a Spatially Heterogeneous Environment: Effects of Genotype-environment Interaction", Genetics Research, 49(2): 147-156.

Via S., GOMUlKiEwicz R., DE JONG G., SCheiner S.M., SChlichting C.D. \& VAN TIENDEREN P.H. (1995), "Adaptative phenotypic plasticity: Consensus and controversy", Trends in Ecology and Evolution, 10(5) : 212-217.

VoGT O. (1926), "Psychiatrisch wichtige Tatsachen der zoologisch-botanischen Systematik", Journal für Psychologie und Neurologie, 101 : 805-832.

W

WADDINGTON C.H. (1938), An introduction to modern genetics, London, George Allen \& Unwin Ltd.

WADDINGTON C.H. (1942), "Canalization of Development and the Inheritance of Acquired Characters", Nature, 150: 563-565.

WADDINGTON C.H. (1953), "Genetic assimilation of an acquired character", Evolution, 7(2): 118-126. 
Waddington C.H. (1961), “Genetic Assimilation”, Advances in Genetics, 10: 257294.

WAGNER G.P.\& AltenBerg L. (1996), “Complex adaptations and the evolution of evolvability", Evolution, 50(3): 967-976.

WEBER B.H.\& DEPEW D.J. (2003), Evolution and learning: the Baldwin effect reconsidered, Cambridge (Mass.), MIT Press.

West-Eberhard M.J. (1989), "Phenotypic Plasticity and the Origins of Diversity", Annual Review of Ecology and Systematics, 20: 249-278.

WeSt-EBERHARD M.J. (2003), Developmental plasticity and evolution, Oxford, Oxford University Press.

WeST-EBERHARD M.J. (2005), "Phenotypic accommodation: adaptive innovation due to developmental plasticity", Journal of Experimental Zoology Part B: Molecular and Developmental Evolution, 304B(6): 610-618.

WOLTERECK R. (1909), "Weitere experimentelle Untersuchungen über Artveränderung, speziel über dasWesen quantitativer Artunterschiede bei Daphnien", Verhandlungen der Deutschen Zoologischen Gesellschaft 19: 110-173.

WriGHT S. (1951), "The genetical structure of population", Annual Eugenics, 15: 323-354.

Z

ZRAZAVY J. \& STYS P. (1997), “The basic body plan of arthropods: insights from evolutionary morphology and developmental biology", Journal of Evolutionary Biology, 10: 353-367 